\title{
Analisis Pendapatan Pedagang Kelontong Di Pasar Syariah Ulul Albab Desa Tanah Merah Dan Pandau Jaya Kecamatan Siak Hulu Kabupaten Kampar
}

\author{
IDEL WALDELMI \\ Dosen Tetap Fakultas Ekonomi Universitas Lancang Kuning \\ Jln. Yos Sudarso KM 8 Rumbai \\ E-mail : idelwaldelmi@unilak.ac.id
}

\begin{abstract}
This research background is based on the existence of modern retail located in shulah ulul albab market environment located between two red land villages and village of pandau jaya subdistrict Siak hulu Kampar regency. The survey was conducted on the merchants by distributing questionnaires that were as many as 34 people and sampling by accidental sampling method. And the data is analyzed by descriptive technique. Based on the result of the research, it is known that the income of sharia market traders after the existence of modern retailing has influence with drastic decline. This drastic decline lies in the income of traders ranging from $1-3$ million to $3.33 \%(23.33 \%-20.00 \%)$ and followed by a decrease in revenues of more than 3 million from $6.67 \%$ and after the presence of modern retail companies No more than 3 million merchant revenues. On the other hand, there was an increase in income to traders with an income of less than 1 million, whereas $70 \%$ of those who made less than 1 million increased to $80 \%$ or increased by $10 \%$ from their previous earnings.
\end{abstract}

Keywords: Sharia Market Traders' Revenue

Bisnis eceren, yang kini populer disebut dengan bisnis ritel, merupakan bisnis yang menghidupi banyak orang dan memberi banyak keuntungan bagi sementara orang lain. Pada saat krisis moneter melanda Indonesia di akhir tahun 1997, yang kemudian berkembang menjadi krisis ekonomi, perekonomian Indonesia banyak tertolong dengan bisnis eceren. Dibanyak negara, termasuk negara-negara terkemuka seperti Prancis, Inggris, dan AS, bisnis eceren merupakan salah satu keuntungan besar (Much Nashirudin 2012)

Persaingan bisnis merupakan konsekuensi dari pada para pelaku usaha, tidak terkecuali perdagangan ritel di Indonesia. Persaingan bisnis ritel ini membelah menjadi dua blok, yang pertama blok ritel tradisional yang secara langsung diwakili oleh toko kelontong serta yang kedua adalah ritel modern yang di wakili minimarket seperti Indomart, Alfamart, Planet Swalayan dan lain sebagainya.

Penyebab terjadinya persaingan antara pedagang harian/ kelontong dengan minimarket adalah karena keduanya memiliki kesamaan, keduanya sama-sama menjual kebutuhan sehari-hari, dari segi komoditas dua ritel ini mempunyai kemiripan hanya model pelayanan dan fasilitas yang berbeda. Menurut Kottler dalam mengklasfikasikan jenis pengecer salah satunya adalah toko kelontong yaitu toko yang pada umumnya berukuran relatif kecil dan terletak di daerah pemukiman, dengan jam buka yang panjang, serta menjual lini produk kebutuhan sehari hari (convenience) yang terbatas dengan tingkat perputaran yang tinggi (Philip Kotler, 2009: 141).

Penyebab terjadinya persaingan antara pedagang harian/ kelontong dengan minimarket adalah karena keduanya memiliki kesamaan, keduanya sama-sama menjual kebutuhan sehari-hari, dari segi komoditas dua ritel ini mempunyai kemiripan hanya model pelayanan dan fasilitas yang berbeda. Menurut Kottler dalam mengklasfikasikan jenis pengecer salah satunya adalah toko kelontong yaitu 
toko yang pada umumnya berukuran relatif kecil dan terletak di daerah pemukiman, dengan jam buka yang panjang, serta menjual lini produk kebutuhan sehari hari (convenience) yang terbatas dengan tingkat perputaran yang tinggi (Philip Kotler, 2009: 141).

Menjamurnya minimarket pada satu sisi, menunjukkan perkembangan perekonomian yang bagus. Pertumbuhan minimarket hingga ke daerah-daerah merupakan eksen dari kemajuan perekonomian Indonesia secara makro. Namun di sisi lain, gairah ekonomi itu ternyata memicu keresahan dikalangan pedagang kelontong. Kehadiran ritel modern tersebut telah memunculkan iklim persaingan yang tidak sehat yang merugikan pedagang kelontong. Tidak menutup kecemburuan sosial di antara para pelaku usaha. Membuat pedagang kelontong khususnya merupakan pedagang dengan modal terbatas, kondisi usaha semakin terpuruk bahkan bisa mati, menurut Sekjen APPSI pertumbuhan minimarket pada satu titik lokasi otomatis mematikan minimal 20 warung masyarakat sehingga menurut Yusup sikumbang "jika izin pendirian terus di keluarkan maka kelangsungan hidup masyarakat paling bawah akan punah" (http://www.riauterkini.com).

Penataan tersebut di harapkan peran pemerintah dapat menjaga stabilitas pasa tradisional. Namun demikian bukan berarti setelah dikeluarkan perpres tersebut telah sesuai dengan apa yang diaharapkan karena masih ada toko modern yang yang menjadi masalah bagi pedagang kelontong seperti yang akan diteliti penulis.

Dari latar belakang diatas penulis ingin Melakukan sebuah penelitian di sebuah pasar di Kecamatan Siak Hulu desa tanah merah dan pandau jaya yang bernama pasar syariah ulul albab dimana sekitar pasar tersebut terdapat bangunan Indomaret, alfamar, Planet swalayan dan swalayan lainnya dengan beberapa meter saja yaitu kurang dari batas minimal 1.000 meter seperti yang telah ditetapkan ditetapkan pemerintah Kabupaten Kampar http://disperindag.kabupatenkampar.go.id

Keberadaan pasar modern memiliki dampak negatif terhadap omset, pendapatan, dan jumlah pelanggan pada usaha ritel Waserda dan pedagang pasar tradisional. Penurunan omset pada usaha ritel Waserda dan pedagang pasar tradisional masing-masing sebesar $24 \%$ dan $16,3 \%$. Sedangkan untuk pendapatan usaha ritel Waserda dan pedagang pasar tradisional masing-masing penurunanya mencapai $30 \%$ dan $17,5 \%$. Selain penurunan omset dan pendapatan, pelaku usaha ritel Waserda dan pedagang pasar tradisional juga mengalami penurunan jumlah pelanggan. Penurunan jumlah pelanggan pedagang pasar tradisional mencapai $32 \%$, sedangkan usaha ritel Waserda mengalami penurunan sebesar 29\% (Eka Yuliasih, 2013).

\section{METODE}

Metode yang digunakan dalam penelitian ini adalah metode penelitian deskriptif. Populasi dalam penelitian ini adalah pedagang pasar syariah ulul albab. Saat ini pedagang harian berjumlah 50 Padagang. Oleh karena relative banyaknya jumlah populasi maka diambil sampel secara proposional random sampling.

Dalam suatu penelitian, peneliti harus menentukan metode apa yang akan digunakan untuk mengumpulkan data dalam rangka menjawab masalah penelitian. Metode penelitian pengumpulan data yang digunakan; Kuesioner; Metode interview (wawancara); Metode observasi ; dan metode dokumentasi. Teknik analisis data yang digunakan adalah teknik deskripfif.

\section{HASIL}

Deskripsi pendapatan padagang pasar syariah setelah adanya keberadaan ritel modern ternyata memberikan pengaruh dengan terjadinya penurunan yang drastis. Penurunan drastis ini terjada pada pendapatan pedagang antara $1-3$ juta yang mencapai kisaran angka 3,33\% ( 23.33

p.ISSN: $2407-800 \mathrm{X}$ e.ISSN: 2541-4356 
$\%-20.00 \%$ ) dan di ikuti dengan penurunan pada pendapatan yang lebih dari 3 juta semula mencapai angka $6.67 \%$ dan setelah keberadaan perusahaan ritel modern tidak ada pendapatan pedagang yang lebih dari 3 juta.

Namun sebaliknya terjadi peningkatan pendapatan pada pedagang yang pendapatanya kurang dari 1 juta dimana semula $70 \%$ padagang berpengasilan kurang dari 1 juta menjadi meningkat menjadi $80 \%$ atau meningkat sebesar $10 \%$ dari penghasilan sebelumnnya.

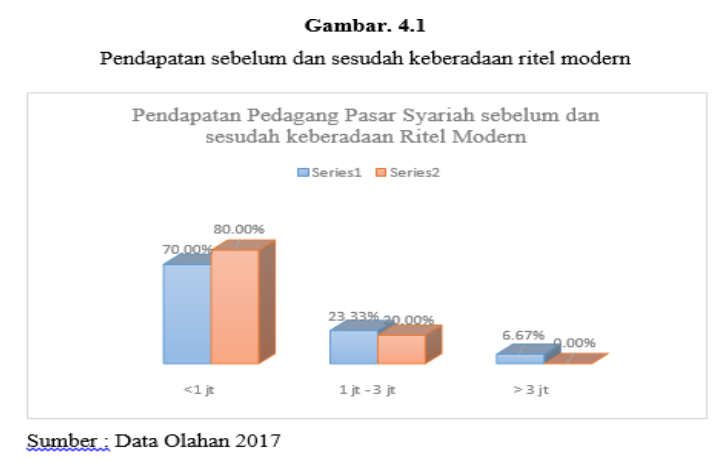

\section{PEMBAHASAN}

Apabila dianalisa penurunan pasca keberadaan ritel modern itu disebabkan oleh beberapa masalah yang lumrah dihadapi antara lain yang dapati dan dijelaskan pada ulasan berikut :

\section{Dengan adanya indomaret pendapatan menurun}

Keberdaan perusahaan ritel memberikan dampak yang luar biasa terhadap pendapatan pedagang khususnya pedagang pasar syariah yang terletak desa tanah merah kecamatan siak hulu kabupaten Kampar. Hal ini dapat dilihat dari survey yang telah dilakukan melalui sebaran kuisioner dan wawancara pada pedagang pasar syariah ulul albab. Pedagang kelontong dengan segala keterbatasanya baik dari segi tempat, financial, kenyamanan dan lainnya dan perusahaan ritel dengan segala kelebihannya baik secara financial maupun tempat serta pelayanan. Sebagai pedagang bagi mereka mampu bertahan saja sudah cukup. Persaingan dunia usaha memang memberikan nilai tersendiri bagi pedagang baik persaingan dengan perusahaan skala besar ritel modern, dengan sesama pedagang dan lainnya. Barang yang dijualpun baik pedagang, perusahaan ritel dimana barang yang dijual hampir sama barang yang dijual tersebut. Hal inilah yang menyebabkan persaingan itu muncul dan memberikan pengaruh terhadap pendapatan pedagang pasar syariah.

\section{Waktu operasional terbatas, kebersihan tempat dan sistem pengambilan barang dari agen}

Pasar syariah yang terletak di desa tanah merah kecamatan siak hulu kabupaten Kampar memilki waktu operasional yang terbatas, walaupun pasar syariah berada pada posisi yang strategis dan di pinggir jalan, karena waktu operasional yang terbatas ini juga menjadi yang dikeluhkan oleh pedagang pasar syariah Beda dengan perusahaan ritel yang waktu operasionalnya hampir 24 jam setiap harinya. Dari segi kebersihan tempat antara pasar syariah dan ritel moden jauh lebih bersih ritel modern tersebut, hal ini bisa dilihat dan dibedakan ketika berbelanja baik di pasar maupun ritel modern tersebut. Kebersihan memang menjadi kendala tersendiri dari pengelola pasar karena banyaknya yang akan dibersihkan dan ditambah di mana semuanya masih serba tradisional. Sistem pengambilan barang dari agen bagi pedagang semuanya di beli dengan serba sedikit, perputaran barang juga lambat, modal yang terbatas dan lainnya, berbeda dengan perusahaan ritel hampir setiap hari barang yang datang dengan mobil membawa barang yang bervariasi dan dengan jumlah yang banyak serta lebih terjamin kualitasnya.

\section{Barang yang dijual sama dengan ritel modern (Indomaret dan alfamart) dengan pedagang}

Dari segi barang yang dijual oleh padagang kelontong pasar syariah hampir semuanya sama baik dari segi makanan, minuman dan lainnya. Ritel modern

p.ISSN: $2407-800 X \quad$ e.ISSN: $2541-4356$ 
memang menjual barang yang sama dengan pedagang pasar syariah namun ada yang berbeda seperti halnya menjual token listrik, pulsa, BPJS, dan angsuran kredit lainnya. Kesamaan inilah yang menyebabkan pedagang tidak mampu bersaing dengan ritel modern yang memiliki kemampuan yang jauh lebih baik di bandingka dengan pedagang eceran. Kondisi ini semakin membuat pedagang tidak mampu bersaing dengan ritel modern yang lokasi yang juga berdekatan satu sama lainnya.

\section{Omset menurun karena perusahaan ritel sering mengadakan promo/ diskon}

Penurunan omset dalam transaksi

bisnis memang suatu pilihan dan merupakan suatu hal yang wajar dengan kondisi persaingan dunia bisnis, baik sekala besar, menengah dan kecil. Namun menjadi tidak wajar dengan persaingan dunia usaha/ bisnis yang tidak sehat, di mana persaiangan ini berlangsung tanpa peduli dengan dunia usaha yang ada di sekitarnya seperti hal yang terjadi pada pedagang kelontong pasar syariah. Kalau dilihat dengan seksama memang persaingan itu luar biasa hebatnya seperti halnya ritel modern memberikan potongan harga/ diskon kepada konsumen dengan berbagai merek dagang yang sama dijual oleh padagang kelontong, potongan harga itu dilakukana dengan cara berkelanjutan dan terus menerus dan dilokasi yang berada di keramaian yaitu pasar itu sendiri. Persaingan bisnis yang tidak berimbang akan menimbulkan permasalahan pada pedagang yang memilki modal yang terbatas dan akan berimbas pada tidak bisa melanjutkan usaha atau tutup karena antara pendapatan dan pengeluaran yang tidak berimbang. Oleh karenanya alangkah baiknya ada peran pemerintah dalam upaya bagaimana melindungan usaha - usaha kecil.

\section{Harga yang rendah dari pasar, waktu pelayanan ritel 24 jam dan dipasar hanya setengan hari}

Persaingan harga memang menjadi permasalahan yang mendasar antara pedagang dan konsumen, dimana bisa dilihat dari kecendrungan konsumen yang selalu membandingkan harga antara pedagang pasar syariah dengan ritel modern yang berada di sekitar pasar syariah tersebut. Memang disatu sisi tidak semua barang yang dijual dipasar lebih mahal dibandingkan dengan ritel modern begitu juga dengan sebaliknya. Waktu pelayanan yang terbatas bagi pedagang pasar dari waktu hingga siang hari hari dari jam 05.00 pagi hingga 13.00 atau lebih, namun konsumen sudah sepi begitu juga pedagang jam 13.00 sudah ada yang tutup. Beda dengan ritel modern yang pelayanannya 24 jam dan sistem bergantian ditambah dengan pelayanan yang bagus, nyaman, dan bersih, inilah yang menjadi daya Tarik bagi konsumen untuk beralah berbelanja dari pasar tradisonal ke pasar modern. Jadi persaingan antara pedagang dengan ritel moden tidak hanya hanya bersaing dengan harga tapi juga bersaingan dengan waktu operasional serta waktu pelayanan terhadap konsumen yang menginginkan barang yang ingin dibeli bisa didapatkan kapan saja.

\section{Konsumen yang beralih ke indomaret/alfamart dalam berbelanja yang padahal dahulunya pelanggan saya}

Membangun emosional dengan pelanggan memang sangat penting karena pelanggan adalah asset yang perlu dirawat dan dijaga, dengan mampu membangun kedekatan secara emosional dengan pelanggan memang pilihan paling penting agar pelanggan tidak berpindah kepada penjual yang lain. Biasanya pedagang yang mampu menjalin hubungam emosional denga pelanggan berapa pun murahnya barang yang dijual oleh pedagang/ritel lainnya tidak akan mempengaruhi pelanggan untuk berpindah membeli barang ke tempat lainnya kecuali memang barang yang dijual tersebut tidak ada/ habis. Kontek harga yang murah memang memiliki daya tarik tersendiri bagi konsumen dalam berbelanja untuk kebutuhan hariannya. Oleh karenanya penting sekali bagaimana menjaga pelanggan, perlu juga diketahui 
bahwasannya dengan terbangunnya kedekatan dengan pelanggan, pedagang bisa saling bertukar pikiran, saling membantu baik ketika pelanggan lagi kekurangan uang alias bisa memberi hutang/ sebaliknya dan saling bertanya kabar berbeda dengan ritel modern yang cendrung hanya sebatas berbalanja dan saling tidak mengenal antara satu sama lainnya. Dengan demikian yang namanya pelanggan tidak akan berpindah hati / berpinh untuk berbelanja.

\section{SIMPULAN}

Pengaruh keberadaan perusahaan ritael terhadap pendapatan pedagang kelontong di pasar syariah ulul albab di desa tanah merah dan desa pandau jaya kecamatan siak hulu kabupaten Kampar, Setelah dideskripsikan mengenai pendapatan pedagang kelontong pada pasar syariah pasca keberadaan ritel modern cendrung mengalami penurunan.

Upaya yang dilakukan oleh pedagang kelontong pasar syariah ulul albab di desa tanah merah dan desa pandau jaya kecamatan siak hulu kabupaten Kampar dalam menghadapi persaingan dengan perusahaan retail tersebut, dengan Pedagang belum sepenuhnya menerapkan sistem syariah pada pasar syariah sehingga menyebabkan Pendapatan terus menurun karena tidak mampu mengimbangi keberaddan ritel modern yang lebih bersih dan harga lebih pasti serta menyediakan barang yang sesuai kebutuhan konsumen sedangkan pada pasar syariah yang semesstinya kebersihan sebagian dari iman masih belum diterapkan, keamanan tidak terjamin padahal berada pada pasar syariah yang menyatakan mencuri adalah perbuatan yang dilarang dan penerapan harga oleh pedagang tidaks sesuai dengan sunnah rasulullah.

\section{DAFTAR RUJUKAN}

Aramiko, S. A. (2011). Dampak Pasar Ritel Modern Terhadap Pasar Dan Pedagang Ritel Tradisional Di Kota Tangerang Selatan Dan Upaya Penanggulangannya.

Pratama, P. Danu. (2015). Analisis Pengaruh Harga Dan Pelayanan Terhadap Keputusan Membeli Di Pasar Tradisional(Studi Pada Pasar Tradisional Jaten Di Daerah Jaten) Vol.03 No, 1-5.

eka Yuliasih. (2013). No Title. Studi Eksplorasi Dampak Keberadaan Pasar Modern Terhadap Usaha Ritel Waserda Dan Pedagang Pasar Tradisional Di Kecamatan Klirong Kabupaten Kebumen, Vol. 3 No., 78-79.

Hasanah, U., \& Winarwati, I. (2011). Studi Potensi Kompetisi Antara Pasar Tradisional Dengan Toko Modern Pasca Peraturan Presiden ( Perpres ) Nomor 112 Tahun 2007 Di Madura , 236-247.

\section{Https://Id.Wikipedia.Org/Wiki/Eceran}

Intruksi Presiden No. 10 Tahun 1999 Tentang Pemberdayaan Usaha Menengah

Keputusan Menteri Keuangan No. 40 /KMK.06/2003 Tentang Pendanaan Kredit Usaha $\quad$ Mikro Dan Kecil

Peraturan Menteri Perdagangan No. 53/MDAG/PER/12/2008 Tentang Pedoman Penataan Dan Pembinaan Pasar Tradisional, Pusat Perbelanjaan Dan Toko $\underline{\text { Modern }}$

Peraturan Menteri Perdagangan No.12 Tahun 2006 Tentang Waralaba 
Maria, A., \& Anggraini, T. (2014). Peranan Industri Kecil-Menengah Dalam Pembangunan Ekonomi Indonesia : Ditinjau Dari Perspektif Hukum Persaingan Usaha, Xiii(3), 441-467.

Fuyi, Nadya. (2014). Analisis Tanggapan 4 Toko Tradisional Pada Waralaba Indomaret/Alfamart (Toko Modern) Di Area Kampus Universitas Jember., Vol. 02 No, 2-3.

Nashirudin. (2012). Dampak Keberadaan Indomaret Terhadap Pendapatan Pedagang Kelontong Di Pasar Cuplik Kecamatan Sukoharjo. Manajemen \& Agribisnis, 11(2), 119-128.
Sarwoko, Endi, 2008. Dampak Keberadaan Pasar Modern Terhadap Kinerja Pedagang Pasar Tradisional Di Wilayah Kabupaten Malang. Jurnal Ekonomi Modernisasi Malang.

Sukirno, Sadono, 2015. Mikro Ekonomi Teori Pengantar. Jakarta. PT. Raja Grafindo Persada.Edisi Ketiga.

Wibowo, Rengkung, M. (2012). Wibowo,Rengkung, Mastutie. Water, Vol 1 No, 114-121.

Zahratain, I., \& Anggraeni, L. (2015). Dampak Perkembangan Toko Modern Terhadap Kinerja Pedagang Produk Pertanian Pada Pasar Tradisional Di Kota Bekasi. Jurnal 